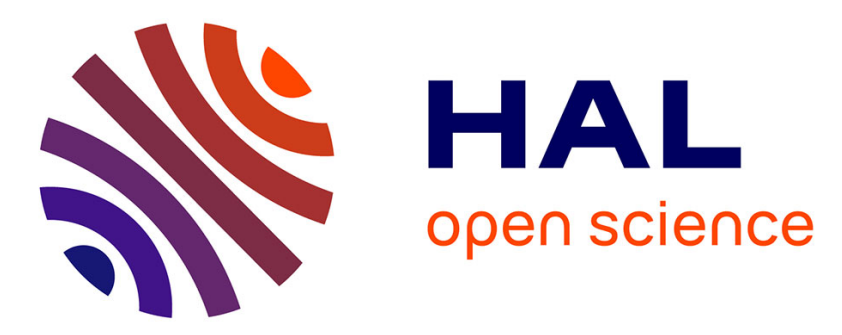

\title{
Demand side management in an integrated electricity market: what are the impacts on generation and environmental concerns? \\ Claire Bergaentzlé, Cédric Clastres
}

\section{To cite this version:}

Claire Bergaentzlé, Cédric Clastres. Demand side management in an integrated electricity market: what are the impacts on generation and environmental concerns?. 10th International Conference on the European Energy Market (EEM 2013), May 2013, Stockholm, Sweden. pp.1-8. halshs-00839116

\section{HAL Id: halshs-00839116 \\ https://shs.hal.science/halshs-00839116}

Submitted on 27 Jun 2013

HAL is a multi-disciplinary open access archive for the deposit and dissemination of scientific research documents, whether they are published or not. The documents may come from teaching and research institutions in France or abroad, or from public or private research centers.
L'archive ouverte pluridisciplinaire HAL, est destinée au dépôt et à la diffusion de documents scientifiques de niveau recherche, publiés ou non, émanant des établissements d'enseignement et de recherche français ou étrangers, des laboratoires publics ou privés. 


\title{
Demand Side Management in an Integrated
}

\section{Electricity Market: What are the Impacts on}

\section{Generation and Environmental Concerns?}

\author{
C. Bergaentzlé, PhD student, Univ. Grenoble Alpes, CNRS, EDDEN-PACTE \\ C. Clastres, Assistant Professor, Univ. Grenoble Alpes, CNRS, EDDEN-PACTE
}

\begin{abstract}
Smart Grid technology appears necessary to succeed in activating the demand through demand side management (DSM) programs. This would in turn improve energy efficiency and achieve environmental targets through controlled consumption. The many pilot projects led worldwide involving smart grids technology, brought quantitative evaluations of DSM measures on electricity load. Efficient DSM instruments must be fine tuned to respond to very specific issues arising from the generation mix, the integration of intermittent energies or the level of outage risks faced during peak period.

Efficient DSM strategies are illustrated through a model involving five countries that carry these different features and under the assumptions of isolated and fully interconnected markets. This paper aims at bringing recommendations regarding the instruments that should be implemented to maximize the benefits of smart grids technology and demand response. Finally, it tends to emphasis the issue of homogenized energy efficiency policies, critical in the building of internal energy markets such as the one the European Union is envisioning.
\end{abstract}

Index Terms-- Demand-Side Management; Dynamic Pricing; Generation Mix; Isolated Market; Integrated market.

\section{INTRODUCTION}

Energy efficiency is one of the means of achieving the targets set by the European Union. The development of smart grids (SG) is a possible solution for achieving these goals [1]. Through their deployment all the players in the electricity supply chain could contribute to system security and stability, with gains subsequently distributed between them. Currently, retail consumers have no way of interacting with the system. Their passiveness is explained by both the fixed rates and the lack of technical ways for price signal to be sent [2]. In the United States $98 \%$ of peak demand is not in a position to adapt its consumption patterns to scarcity conditions [3]. This matter is seen as one of the key structural problems in electricity markets [4]. The activation of demand would become a source of flexibility when balancing supply and demand.

Deploying SG technology should consequently restore the missing link between the system and consumers and enhance the system efficiency . Modernization of distribution networks and metering technology is opening the way for new energy packages and prices, with in particular greater scope for controlling and managing demand. A generation bid may thus be replaced by load-shedding or shifting, which can be sold on the market [5], [6]. Many pilot studies have been carried out to study demand response (DR) in the US and more recently in Europe [7]-[9]. The initial conclusions suggest that peak loadshedding may be significant [10]. Demand elasticity affects both the cost of energy (energy efficiency) and efforts to reduce greenhouse-gas emissions (environmental efficiency).

We will first focus on the use of price signals to elicit a demand response from the retail market. We shall show that these signals do allow demand to be managed with consumers responding to price signals. As has often been observed, deploying several information or price-based tools yields the best results. In the second part we present a quantitative study of gains in energy and environmental efficiency linked to demand-side management. We shall see that these gains depend in particular on the generation technologies being used and on the energy policies limiting changes in the mix.

\section{DEMAND RESPONSE AND RETAIL CONSUMERS}

Deploying smart-grid technology is a key component in the development of demand-side management schemes. As underlined by many authors [10]-[16] demand response (DR) can yield significant economic and environmental gains.

Demand response techniques may be divided into two main categories: voluntary load management by consumers themselves through dynamic pricing; and automatic systems controlled by a third parties [17].

\section{A. Demand-response instruments for retail consumers}

Time-of-use (ToU) pricing breaks down the day into set periods of time, each associated with a specific, predetermined price. This is the simplest and most commonly used form of dynamic pricing. However it only allows limited flexibility, often with only slight differences between baseline and peak periods [18]. Critical-peak pricing (CPP) responds to the criticism regarding flexibility. It is based on the same principles as ToU but segments periods with a finer mesh (baseline, peak and several critical-peak periods). A warning signal is sent to consumers alerting them to a critical-peak period. Real-time pricing (RTP) transmits variations in the 
wholesale price per $\mathrm{kWh}$ to consumers. Peak-time rebate (PTR) systems differ from the others: rather than being based on the principle of a surcharge for peak consumption, PTR rewards a drop in consumption for such periods, in relation to the baseline load curve.

For such pricing systems to be widely deployed residential premises must be equipped with smart meters able to measure, record and charge the rate stipulated by the pricing scheme. Alongside smart meters, smart technologies are being developed, ultimately leading to the appearance of smart spaces capable of managing their electricity requirements optimally, using remote-management or direct load-control (DLC) systems.

\section{B. Dynamic pricing and load reductions}

Broadcasting information is a critical factor in the success of any DR scheme. Various studies have shown that just the presence of in-home displays (IHD), or interfaces, could constitute an incentive to change consumption patterns. The study by Faruqui et al, 2010a shows that their impacts in reducing demand range from $1.8 \%$ to $6.7 \%$ on average [8]. Applying both IHD communication and dynamic pricing increases these results as the pilot carried out by Hydro One, Ontario, suggests. It revealed IHD + ToU could lead to a $7.3 \%$ peak load reduction. This conclusion differs substantially from the result obtained by transmitting information (brochure or mail-shot). Schemes simply informing consumers, tested in California, were not a sufficient inducement to achieve loadreduction [19].

California provides a complete example of experimentation with DSM. The studies carried out by Faruqui et al. (2008), and by Wolak, (2006) on pilot schemes in this state, revealed that a combination of pricing and warning signals (CPP and PTR) has an impact three to seven times greater on reducing peak consumption than a ToU pricing system [19], [20].

The study led by Faruqui et al, (2010b) which compiled the results of 28 pilot schemes carried out by 15 utilities in the US and Canada, revealed similar results, which summarized below in Table I [9]. This study shows that the average load reduction with ToU is $4 \%$. Higher results $-13 \%$ and $17 \%-$ were obtained with more complex, PTR or CPP schemes, respectively. Lastly, the use of advanced technology such as smart thermostats coupled with IHDs proved essential to induce more substantial reductions in load. This combination doubled the average peak-hour reduction with CPP, and showed a six fold gain on comparable consumption with ToU (down by $36 \%$ and $26 \%$ respectively).

\section{TABLE I}

Impact on load of pricing and smart technologies in 28 pilot schemes.

\begin{tabular}{|c|c|c|}
\hline & $\begin{array}{c}\text { Number of } \\
\text { observations }\end{array}$ & $\begin{array}{c}\text { Average drop in } \\
\text { peak load }\end{array}$ \\
\hline ToU & 5 & $4 \%$ \\
\hline $\begin{array}{c}\text { ToU + smart } \\
\text { technology }\end{array}$ & 4 & $26 \%$ \\
\hline PTR & 3 & $13 \%$ \\
\hline CPP & 8 & $17 \%$ \\
\hline $\begin{array}{c}\text { CPP }+ \text { smart } \\
\text { technology }\end{array}$ & 8 & $36 \%$ \\
\hline
\end{tabular}

Source: Faruqui et al. (2010b) [9].

Regarding RTP, theoretical research concludes that deploying RTP at all retail sites would achieve 'optimum allocation with no deadweight loss' [15]. However empirical experiments indicate only limited success with RTP, it being too complicated for consumers to manage [13]. Coupling RTP with a load-management technology and signalling is one way of overcoming this shortcoming. With automation, consumers can set a threshold price above which their marginal propensity to consume is zero and leave it up to the operator to control their consumption automatically in real time. This combination was tested as part of a pilot scheme in Austria [21]. In this instance the impact of RTP was twice as high on peak-demand days than at periods subject to less stress $(10 \%$ and $5.3 \%$ respectively). Secondly an RTP + control system boosted the results to $16.2 \%$ and $7.3 \%$, respectively.

An earlier study described DLC as the best instrument for reducing the peak load of residential consumers [10]. Tthis study estimated that peak consumption in the US could probably be cut by $5 \%$. This reduction would represent an annual gain of between $\$ 8 \mathrm{bn}$ and $\$ 13 \mathrm{bn}$, of which $\$ 5 \mathrm{bn}$ to $\$ 10 \mathrm{bn}$ would be due to a drop in the short term price of energy. The difference represents long-term gains yielded by avoided investment in additional generation and transmissiondistribution capacity.

The same methodology was used for the European market [22]. This study was unable to estimate the short-term economic gains yielded by demand response, but it did show that Europe could realistically reduce peak demand by $8 \%$ to $10 \%$ simply through pricing. Deployment of load-control technology coupled with dynamic pricing would cut peak demand by $12 \%$ to $19 \%$.

Lastly, although a reduction in load automatically permits an instantaneous drop in generation, these studies do not provide any indication of the effect of shifting demand. Indeed, consumers may respond to a price variation in two ways: either by a net reduction in consumption; or by delaying usage [23]. The greater the load-shedding, the more delayed consumption must be controlled and spread over several hours. If all the consumption halted by load-shedding is simply shifted to off-peak hours then the efficiency gains expected of DSM will be seriously reduced [24]

An optimal choice of demand-side management tools is required, making allowance for their respective advantages and bringing them into line with real needs and the technology mix of the country or region in which they are deployed, the priority goal being to reduce costs. 


\section{DEMAND-SIDE MANAGEMENT : ILLUSTRATION WITH FIVE COUNTRIES}

Our example with five countries studies the impact of demand-side management on generation costs and greenhouse-gas emissions. We have modelled five separate countries, each equipped with its own generation resources with specific costs for each generation technology ${ }^{1}$ (Appendix $1)$.

We have assumed there are two periods of consumption: a peak period, at $19.00(7 \mathrm{pm})$, and an off-peak period, at 04.00 (4am). Appendix 2 gives the net consumption values for these two periods.

A tonne of $\mathrm{CO}_{2}$ is valued at $€ 14.18$ (Bluenext value on 17 January 2011 corresponding to the period of consumption covered by our study). Appendix 3 shows the contribution of each generation technology to carbon emissions.

The various countries are looking for ways of minimizing overall costs, while balancing supply and demand. The optimization programme here aims to minimize total generation costs for each country, as a function of the quantity produced to serve domestic demand.

We asume installed capacity can never achieve full output. Allowance is made for the available production factors as a function of a technology's installed capacity $\mathrm{K}_{\mathrm{ij}}$ (see Appendix $3)$.

In the absence of interconnections each country can only draw on its own generation capacity to balance market supply and demand. Table II details marginal generation resources enlisted during the peak and off-peak hours covered by the study. In this context, we may distinguish two groups. The first comprises Spain, the Netherlands and Germany. Their installed and available (particularly fossil-fuel) capacity is sufficiently large to satisfy domestic consumption. During peak hour, wind and nuclear energy in Spain and the Netherlands respectively are not retained in the merit order because of their cost. Similarly Germany does not use its oilfired critical-peak power plants. The second group comprises Belgium and France, which are subject to stress because they use all their available generation resources. Indeed Belgium has a power shortage and cannot balance its market.

\section{TABLE II}

Results of supply/demand balance - Separate countries

\footnotetext{
${ }^{1}$ Data on the cost of generation are the private property of firms. It is consequently difficult to observe or calculate such data. The cost here is an approximation based on available data relating to the Capex, Opex and load factor figures for each country. The values are the authors' own estimates.
}

\begin{tabular}{|c|c|c|}
\hline & $\begin{array}{c}\text { Marginal } \\
\text { generation cos tat } \\
19.00(€ / \mathrm{MWh})\end{array}$ & $\begin{array}{c}\text { Marginal } \\
\text { generation cos tat } \\
04.00(€ / \mathrm{MWh})\end{array}$ \\
\hline Spain & 33 (gas) & 33 (gas) \\
\hline Netherlands & 22 (gas) & 22 (gas) \\
\hline Germany & 43 (coal) & 43 (coal) \\
\hline France & 168 (oil) & 22 (nuclear) \\
\hline Belgium & $\begin{array}{c}\text { Indeterminate } \\
\text { (VOLL) }\end{array}$ & 24 (gas) \\
\hline
\end{tabular}

This baseline situation shows that all the countries would gain by applying DSM, some to reduce their emissions, others to reduce stress on their electricity system. So, for each country we calculated the total cost of supplying energy for various scenarios regarding the generation mix coupled with DSM, with demand shifted or not to off-peak hours. Unless stipulated, the volume of load-shifting is always equal to the full amount of peak-hour load-shedding. The calculated total cost will be made up of the sum of the total cost of energy and $\mathrm{CO}_{2}$ over the two periods under study.

\section{A. Demand response and stress on the electricity system}

France balances peak supply and demand by using its oilfired power stations, at a high financial ( $€ 168$ per MWh) and environmental cost. On the other hand hydraulic and nuclear ( $€ 22$ per MWh) power stations cater for off-peak demand, at a low cost and with no emissions. The total cost (baseline) to serve demand over the two periods is $€ 15,319,979$.

A $2 \%$ load-shedding results in positive balance (Table III), avoiding the need to draw on oil-fired plant, with gas-fired plant balancing the system. The overall cost is reduced by $29.1 \%$. The result would be even better if $10 \%$ load-shedding could be achieved, with a $52.9 \%$ saving on the overall cost. There no longer being any need for oil or gas-fired plant at peak hours, coal-fired plant costing $€ 50$ per MWh can be used to balance supply and demand. With $10 \%$ load-shedding there is only marginal coal-fired generation. On the other hand, higher load-shedding (17\%) substantially reduces the cost at peak load, but load-shifting only yields a $27.9 \%$ saving, in other words a meagre gain compared with only $2 \%$ shedding. Load-shifting has a major impact on the cost of energy (the marginal power plant being gas-fired, at a cost of $€ 113$ per MWh) and on emissions (with coal-fired plants operating at full capacity in addition to the marginal gas plant). Substantial load-shedding should therefore be followed by graduated shifting.

\section{TABLE III}

Impact of load-shedding and shifting on costs for France

\begin{tabular}{|c|c|c|c|}
\hline $\begin{array}{c}\text { Shifted load } \\
(\%)\end{array}$ & $\begin{array}{c}\text { Cut in } \\
\text { energy } \\
\text { cost }(\%)\end{array}$ & $\begin{array}{c}\text { Cut in } \\
\text { emissions cost } \\
\text { CO2 }(\%)\end{array}$ & $\begin{array}{c}\text { Overall cut in } \\
\text { cost }(\%)\end{array}$ \\
\hline 2 & 29.2 & 13 & 29.1 \\
\hline 10 & 52.9 & 37.5 & 52.8 \\
\hline 17 & 27.8 & 38.5 & 27.9 \\
\hline
\end{tabular}

Load-shedding thus improves generation and environmental efficiency even though all the load that is shed is ultimately just delayed. On the other hand a strategy involving the greatest possible load-shedding only yields optimal results 
with a low reconnection rate. In the case of full reconnection it is not optimal at all. Shedding $2 \%$ of the load can be more efficient and does not involve deploying sophisticated instruments. In fact good information broadcasting can achieve the same result [22] On the other hand, more substantial shedding, in the range of $10 \%$ to $17 \%$, requires the introduction of more complex measures, combining CPP or RTP with information and/or control instruments.

The situation in Belgium is more worrying, as it is unable to satisfy peak demand exclusively with its own resources (Table II). By shedding $5 \%$ of the load the market can be balanced. We used this point of balance as a baseline in the following tables to calculate the gains derived from additional loadshedding, a measure which is profitable and necessary for the market to function. With load-shedding at this level, peak demand is balanced thanks to oil-fired plant ( $€ 164$ per MWh). The overall cost, or baseline, to cater for peak and off-peak demand is $€ 2,041,887$.

The most effective level of load-shedding corresponds to roughly $13 \%$ of demand (Table IV). This level yields substantial efficiency gains even in the event of subsequent load reconnection $(51.5 \%$ cut in overall costs). Oil-fired plant previously used to meet critical-peak demand would no longer generate power at peak hours, yielding a significant cut in energy costs. Furthermore load reconnection only has a slight impact on off-peak energy costs and emissions (only limited coal-fired generation is required). With $5 \%$ of demand shifted to 04.00 there is an increase in the cost of energy and in emissions. During off-peak hours hydraulic power ( $€ 25$ per $\mathrm{MWh}$ ) takes over as the marginal plant, with gas-fired plants operating at full capacity, boosting $\mathrm{CO}_{2}$ emissions. Shedding $21 \%$ of the load also cuts both the cost of energy and emissions, but if all demand is simply shifted to off-peak hours there is no gain in efficiency because of the high cost of fossil-fuel plant operating at that time.

TABLE IV

Impact on costs of shedding more than $5 \%$ of the load, in part shifted

\begin{tabular}{|c|c|c|c|}
\hline $\begin{array}{c}\text { Load- } \\
\text { shedding at } \\
19.00(\%)\end{array}$ & $\begin{array}{c}\text { Reduction in } \\
\text { energy cost } \\
(\%)\end{array}$ & $\begin{array}{c}\text { Cut in } \\
\text { emissions cost } \\
\text { CO2 }(\%)\end{array}$ & $\begin{array}{c}\text { Overall } \\
\text { reduction in } \\
\text { cost }(\%)\end{array}$ \\
\hline 13 & 66.4 & 15.4 & 64.7 \\
\hline 21 & 74.4 & 31.9 & 73 \\
\hline $\begin{array}{c}5 \% \text { shifted to } \\
4.00\end{array}$ & -1.1 & -0.6 & -1.1 \\
\hline $\begin{array}{c}13 \% \text { shifted } \\
\text { to } 4.00\end{array}$ & 53.3 & 1.6 & 51.5 \\
\hline $\begin{array}{c}21 \% \text { shifted } \\
\text { to } 4.00\end{array}$ & -3.4 & 3.8 & -3.1 \\
\hline
\end{tabular}

Here again, there is no call for major incentive measures to shift $5 \%$ of the load, thus balancing supply and demand. On the other hand much more work will be required to change the marginal power plant (in the event of load-shedding ranging from $13 \%$ to $21 \%$ ). As in the previous case this would involve the use of several incentives and information instruments. However it would not be ideal to shed a substantial share of demand unless the impact of shifting is spread over several hours.

\section{B. Demand response and environmental efficiency}

These countries have substantial generation capacity at their disposal to serve peak demand. They are thus able to balance peak supply and demand, but each MWh comes at a high cost in emissions. There seems little scope here for reducing consumption in order to bring down the unit cost of energy due to the scale of fossil-fuel capacity. On the other hand, measures enabling generation with more environmentally friendly technologies could be worthwhile, thanks to the cut in emissions.

Spain has two ways of reducing overall generation costs: to give priority to developing wind power; and to deploy DSM measures. Shifting peak-generation from gas-fired plants to wind farms, despite a higher unit cost (see Appendix 1) would reduce the cost of $\mathrm{CO}_{2}$ emissions. The extra cost of wind power could then be reduced by shedding $15.3 \%$ of demand. We have taken as a baseline the total cost, without wind power, of $€ 2,321,114$ for serving both consumption periods.

We studied two scenarios for introducing wind power. In the first case its introduction follows a conventional pattern, the price of wind power being equal to the marginal price $(€ 41$ per $\mathrm{MWh}$ ). In the second scenario we assumed a premiumtype system, which enables renewable-energy generators to recover, at least, the difference between the market price and their overall costs (the market price of the marginal power plant remains that of gas, €33 per MWh).

The introduction of wind-powered generation entails an increase in the overall cost, in all the scenarios, except with a premium system without load-shifting, which yields efficiency gains (see Table V). The gains derived from lower $\mathrm{CO}_{2}$ emissions compensate the excess cost entailed by the premium incentive mechanism. Demand control improves results, but in so far as possible it should not involve all the load that is shed being shifted to off-peak hours, as the marginal plants burn fossil fuel. Shifting consumption to off-peak hours would certainly not impact on the unit cost of energy but it would increase $\mathrm{CO}_{2}$ emissions for that period, leading to a drop in efficiency.

\section{TABLE V}

Impact of load-shedding on overall costs compared with the initial (baseline) situation

\begin{tabular}{||c|c|c|c|}
\hline & $\begin{array}{c}\text { Cut in total } \\
\text { cost without } \\
\text { DSM (\%) }\end{array}$ & $\begin{array}{c}\text { Cut in total } \\
\text { cost with } \\
15.3 \% \text { DSM } \\
(\%)\end{array}$ & $\begin{array}{c}\text { Cut in total } \\
\text { cost with } \\
15.3 \% \text { DSM } \\
\text { shifted at } \\
4.00(\%)\end{array}$ \\
\hline $\begin{array}{c}\text { Without } \\
\text { including wind } \\
\text { power }\end{array}$ & $\begin{array}{c}\text { Baseline : } \\
\text { total cost of } \\
€ 2,321,114\end{array}$ & 10.1 & 0 \\
\hline $\begin{array}{c}\text { Including wind } \\
\text { power }\end{array}$ & -19.3 & -7.1 & -10.1 \\
\hline $\begin{array}{c}\text { With wind } \\
\text { power and } \\
\text { premium }\end{array}$ & -1.3 & 9.9 & -1.2 \\
\hline
\end{tabular}


By managing demand (shifted or not) gains in environmental and energy efficiency can be achieved. As these gains mainly concern greenhouse-gas emissions, efficiency increases with the scale of DSM deployed. If the load is simply shifted, efficiency suffers, as the marginal plants burn fossil fuel. The best combination of solutions for substantially cutting demand would be dynamic pricing with control and information systems.

Exactly the same reasoning and conclusions apply to the Netherlands as to Spain, with fossil-fuel marginal plants and carbon-free (nuclear and wind-power) resources which are both costly and insufficient in number to offer a plausible alternative to gas-fired resources.

On the other hand, Germany differs from Spain and the Netherlands in that it uses all its carbon-free resources to balance peak supply and demand. A DSM strategy is fully operative in this instance, allowing reduced use of coal-fired plants. With coal-fired generation serving $48 \%$ of demand, extensive load-shedding would be required to change the marginal generation technology. As a result any load-shedding contributes to reducing $\mathrm{CO}_{2}$ emissions. But, of course, simply shifting this demand to off-peak hours would cancel any gains, the marginal power plants being coal-fired.

A scenario in which Germany gives up the use of nuclear power would substantially alter these conclusions. With no nuclear power, the gas and oil-fired peaking plants (costing respectively $€ 113$ and $€ 164$ per $\mathrm{MWh}$ ) would be required to serve peak demand, raising energy and emissions costs. Under these circumstances DSM could have a positive impact on both emissions and the cost of energy. We have consequently analysed the eventuality of Germany decommissioning its nuclear plants, with two scenarios for controlling demand: $3.45 \%$ load-shedding to avoid using oil-fired plants (the peakhour marginal power plant would be gas-fired); and $14 \%$ loadshedding to end the use of gas-fired resources (the peak-hour marginal power plant would be coal-fired). The total cost of generation under the scenario with nuclear power would be $€ 6,586,119$, whereas without nuclear power it would be $€ 16,646,209$.

Even with demand being shifted, DSM would reduce overall costs (see Table VI). The impact of DSM is of course greater in the scenario without nuclear power, because the very expensive oil and gas-fired marginal plants would be replaced by their coal-fired counterparts, resulting in higher emissions but much lower costs. The emissions balance-sheet is nevertheless negative because coal-fired resources would be used for off-peak hours, taking over from the gas and oil-fired peak plants.

TABLE VI

Impact of DSM on total costs

\begin{tabular}{|c|c|c|c|c|}
\hline & $\begin{array}{c}\text { Cut in total } \\
\text { cost with } \\
3.45 \% \text { DSM } \\
\text { without } \\
\text { shifting }(\%)\end{array}$ & $\begin{array}{c}\text { Cut in total } \\
\text { cost with } \\
14 \% \text { DSM } \\
\text { without } \\
\text { shifting }(\%)\end{array}$ & $\begin{array}{c}\text { Cut in total } \\
\text { cost with } \\
3.45 \% \\
\text { DSM } \\
\text { shifted at } \\
4.00(\%)\end{array}$ & $\begin{array}{c}\text { Cut in total } \\
\text { cost with } \\
14 \% \text { DSM } \\
\text { shifted at } \\
4.00(\%)\end{array}$ \\
\hline $\begin{array}{l}\text { With } \\
\text { nuclear } \\
\text { power }\end{array}$ & 3.1 & 10.3 & 0 & 0 \\
\hline $\begin{array}{l}\text { Without } \\
\text { nuclear } \\
\text { power }\end{array}$ & 26.5 & 61.4 & 25.6 & 57.6 \\
\hline
\end{tabular}

If nuclear power is retained, DSM without load-shifting only impacts on emissions but not on the unit cost of energy, because the same marginal plant is used. If demand is simply shifted it cancels out any gains, the same (coal-fired) marginal plants operating off-peak as at peak hours. On the other hand, without nuclear power DSM would have greater effect, yielding a significant cut in the unit cost of energy. However this effect is limited if demand is simply shifted, due to the higher $\mathrm{CO}_{2}$ emissions at off-peak hours. To maintain the balance of supply and demand, without the support of nuclear power, Germany would need to introduce substantial (14\%) DSM in order to avoid an increase in the unit cost of energy and to contain emissions. If so, deploying demand control with dynamic pricing and a high-performance information system would be a useful addition to other possible measures such as increasing use of gas or renewables combined cycles.

\section{An interconnected market with no limit on capacity}

At this point we introduced the possibility for each country to trade as much energy with its neighbours as it wished. Under the present European Union merit order, German coalfired power plants (with a $€ 43$ per MWh generation cost) would be used to serve aggregate demand at peak hours. Spanish gas-fired plants, costing $€ 33$ per MWh, would balance supply and demand at off-peak hours. As may be expected this situation leads to increased generation efficiency compared with the previous case.

Costs can be improved and optimized by managing active demand. A $17 \%$ reduction in demand could be achieved if Germany continued using nuclear power, providing for a reduction in the cost of energy (the marginal resource would be Spanish wind power costing $€ 41$ per MWh) but also a significant drop in the cost of emissions (table VII). To achieve this level of load-shedding, countries could pool their efforts. To achieve a $17 \%$ cross-the-board reduction in peak demand it would be necessary to deploy powerful information systems and incentive instruments (critical-peak or real-time pricing), backed by load control by suppliers, TSOs or DSOs. Whereas national strategies only involved basic measures to reduce or shift demand, a collective strategy would require direct investment in complex systems for implementing and managing load-shedding.

Over and above $77 \%$ shifting of demand to off-peak hours after load-shedding, any reduction in the cost of energy would be counter-balanced by the use of additional plants during offpeak hours. Load-shifting on this scale would entail additional costs in terms of energy but not necessarily for $\mathrm{CO}_{2}$ emissions, 
due to the use of more costly wind power. Load-shedding strategies would be beneficial, all the more so if the timing or volume of reconnections were controlled to prevent simply shifting peak consumption.

The results would be significantly different if Germany phased out nuclear power. DSM under $4.57 \%$ would have no impact on the cost of energy, because even with a switch in marginal resources (Belgian and Spanish plants are interchangeable), the cost would be the same.

TABLE VII

Impact of DSM on overall costs in an interconnected space with unlimited transit

\begin{tabular}{|c|c|c|c|c|}
\hline & $\begin{array}{c}\text { Total } \\
\text { baseline } \\
\text { cost }(€)\end{array}$ & $\begin{array}{c}\text { Shedding } \\
\text { of demand } \\
\text { at } 19.00 \\
(\%)\end{array}$ & $\begin{array}{c}\text { Reduction } \\
\text { in total } \\
\text { cost } \\
\text { without } \\
\text { shifting } \\
(\%)\end{array}$ & $\begin{array}{c}\text { Reduction } \\
\text { in total } \\
\text { cost with } \\
\text { shifting } \\
(\%)\end{array}$ \\
\hline $\begin{array}{c}\text { With } \\
\text { German } \\
\text { nuclear } \\
\text { power }\end{array}$ & $16,469,689$ & 17 & 16 & -48 \\
\hline $\begin{array}{c}\text { Without } \\
\text { German } \\
\text { nuclear } \\
\text { power }\end{array}$ & $18,676,161$ & 4.57 & 7 & 3 \\
\cline { 3 - 5 } & & 25.1 & 51 & 31 \\
\hline
\end{tabular}

\section{CONCLUSION}

Managing demand through various pricing and information systems provides a way of reducing consumption at peak hours. The various experiments cited here show that several instruments are better suited to high levels of load-shedding. But such measures upset market equilibrium and change $\mathrm{CO}_{2}$ emissions.

The positive or negative impacts of such changes depend on the extent of load-shedding, the generation mix and the volume of demand-shifting.
A simple example corroborates these results. Deploying energy-efficiency measures and incentives naturally leads to an improvement of the situation in the various countries covered by our study. The scale of the measures required to control demand and shed the corresponding load depends on both the generation mix and the gap between supply and demand. Demand-shifting is optimal when it is spread over several off-peak hours, the costs of energy and emissions being diluted over this period, which limits their scale. If the full load is simply shifted to a specific time later on - the result of uncontrolled reconnection of load shed - the various situations reveal a real difference regarding the cost of energy and emissions. There is also a change in the marginal power resources serving off-peak demand, raising the cost of energygeneration and emissions when a majority of fossil-fuel resources are used.

These examples highlight the DSM policies best suited to isolated countries. The countries where a delicate balance prevails, powered by low-emissions generation, should give priority to simple demand-side management tools. On the other hand, it seems that countries hampered by high emissions, albeit without any serious risk of failure, should opt for the more complex (and expensive) pricing and control tools.

However a substantially different conclusion emerges, if the scope of the present exercise is enlarged to define an optimal DSM policy for a situation in which these countries are not only interconnected but also bound by EU-wide energyefficiency targets. In this case a common goal takes priority over national goals, with $17 \%$ being the optimal level of DSM if Germany retains its nuclear power plants, dropping to no less than $4.57 \%$ in the eventuality of Germany phasing out nuclear power. The latter measure would entail increased use of marginal, coal-fired plants, but more extensive DSM would limit the need for such resources, with a corresponding impact on the unit cost of energy and emissions.

\section{APPENDIX}

Appendix 1: Electricity generation capacities and costs in various European countries in 2010

\begin{tabular}{|c|c|c|c|c|c|c|c|c|c|c|}
\hline Country j & \multicolumn{2}{|c|}{ Spain } & \multicolumn{2}{|c|}{ Netherlands } & \multicolumn{2}{|c|}{ Germany } & \multicolumn{2}{|c|}{ France } & \multicolumn{2}{|c|}{ Belgium } \\
\hline $\begin{array}{c}\text { generation } \\
\text { technology } \\
\text { i }\end{array}$ & $\begin{array}{c}\text { Installed } \\
\text { capacity } \\
\text { (MW) }\end{array}$ & $\begin{array}{c}\text { Cost } \\
€ / M W h\end{array}$ & $\begin{array}{c}\text { Installed } \\
\text { capacity } \\
\text { (MW) }\end{array}$ & $\begin{array}{l}\text { Cost } \\
€ / M W h\end{array}$ & $\begin{array}{c}\text { Installed } \\
\text { capacity } \\
\text { (MW) }\end{array}$ & $\begin{array}{c}\text { Cost } \\
€ / M W h\end{array}$ & $\begin{array}{c}\text { Installed } \\
\text { capacity } \\
\text { (MW) }\end{array}$ & $\begin{array}{c}\text { Cost } \\
€ / \mathrm{MWh}\end{array}$ & $\begin{array}{c}\text { Installed } \\
\text { capacity } \\
\text { (MW) }\end{array}$ & $\begin{array}{l}\text { Cost } \\
€ / \mathrm{MWh}\end{array}$ \\
\hline Gas & \multirow[b]{2}{*}{$\begin{array}{c}33,465 \\
40\end{array}$} & \multirow[b]{2}{*}{33} & \multirow[b]{2}{*}{23,270} & \multirow[b]{2}{*}{22} & 9,810 & 113 & \multirow[b]{2}{*}{7,497} & \multirow[b]{2}{*}{116} & \multirow[b]{2}{*}{5,985} & \multirow[b]{2}{*}{24} \\
\hline $\begin{array}{c}\text { Combined } \\
\text { cycles }\end{array}$ & & & & & 12,000 & 30 & & & & \\
\hline Oil & 6,436 & 164 & 789 & 164 & 5,856 & 164 & 13,244 & 168 & 1,340 & 164 \\
\hline Coal & 12,070 & 47 & 3,346 & 44 & 52,837 & 43 & 7,257 & 50 & 1,195 & 47 \\
\hline Wind & 20,676 & 41 & 2,449 & 37 & 27,157 & 39 & 6,080 & 37 & 912 & 34 \\
\hline $\begin{array}{l}\text { Hydro } \\
\text { (peak) }\end{array}$ & 5,350 & 29 & - & - & 6,470 & 29 & 5,100 & 27 & 1,310 & 25 \\
\hline $\begin{array}{c}\text { Hydro } \\
\text { (baseline) }\end{array}$ & 13,020 & 15 & 37 & 15 & 4,550 & 15 & 20,570 & 13 & 110 & 15 \\
\hline Nuclear & 7,450 & 23 & 482 & 23 & 20,467 & 23 & 63,130 & 22 & 5,830 & 23 \\
\hline Total & 98,467 & & 30,373 & & 127,147 & & 122,879 & & 16,683 & \\
\hline
\end{tabular}

Sources: IEA (2012) [25] and authors' data. 
Appendix 2: Consumption (Cj) on 19 January 2011 in each country (MWh)

\begin{tabular}{|c|c|c|c|c|c|}
\hline Period & Spain & Netherlands & Germany & France & Belgium \\
\hline 19.00 & 39,694 & 16,826 & 79,863 & 82,450 & 13,881 \\
\hline 04.00 & 24,934 & 9,898 & 54,635 & 60,536 & 10,002 \\
\hline
\end{tabular}

Source: Data provided by ENTSO-E

Appendix 3: Available generation and $\mathrm{CO}_{2}$ emissions for each generation technology

\begin{tabular}{|c|c|c|}
\hline generation technology & Available generation $(\mathrm{MWh})$ & $\mathrm{CO}_{2}$ emissions $\left(\mathrm{tCO}_{2} / \mathrm{MWh}\right)$ \\
\hline Coal & $0.85 * \mathrm{~K}_{\text {Coal }}$ & 0.96 \\
\hline Gas & $0.85 * \mathrm{~K}_{\text {Gas }}$ & 0.4 \\
\hline Combined cycle & $0.85 * \mathrm{~K}_{\text {Combined_cycles }}$ & 0.36 \\
\hline Oil & $0.85 * \mathrm{~K}_{\text {Oil }}$ & 0.8 \\
\hline Wind & $0.3 * \mathrm{~K}_{\text {Wind }}$ & 0 \\
\hline Hydro & $0.5 * \mathrm{~K}_{\text {Hydro }}$ & 0 \\
\hline Nuclear & $0.85 * \mathrm{~K}_{\text {Nuclear }}$ & 0 \\
\hline
\end{tabular}

Sources: EIA, 2010 [26]

\section{REFERENCES}

[1] CLASTRES C., "Smart grids: Another step towards competition, energy security and climate change objectives" Original Research Article Energy Policy, Volume 39, Issue 9, September 2011, Pages 53995408.

[2] CHAO H. P., "Demand response in wholesale electricity markets: the choice of customer baseline", Journal of Regulatory Economics, vol. 39, issue 1, February 2011, p. $68-88$.

[3] JOSKOW P. L., "Competitive Electricity Markets and Investment in New Generating Capacity.” MIT CEEPR Working Paper 06-009, April.

[4] STOFT S., "Power System Economics: Designing Markets for Electricity", IEEE Press, Piscataway, New Jersey, 2002.

[5] CAPPERS P., GOLDMAN C., KATHAN D., "Demand Response in U.S. Electricity Markets: Empirical Evidence", Energy, Volume 35, Issue 4, April 2010, Pages 1526-1535.

[6] CRAMPES C., LEAUTIER T.O., (2010) « Dispatching, redispatching et effacement de demande », Institut d'Economie Industrielle, Toulouse, septembre.

[7] COLL-MAYOR D., PAGET M., LIGHTNER E., "Future intelligent power grids: Analysis of the vision in the European Union and the United States", Energy Policy, Volume 35, Issue 4, April 2007, Pages 2453-2465

[8] FARUQUI A., SERGICI, S., (2010a), "Household response to dynamic pricing of electricity: a survey of 15 experiments", Journal of Regulatory Economics, Vol.38, n², October 2010, p. 193-225.

[9] FARUQUI A., HARRIS D., HLEDIK R., (2010b), "Unlocking the €53 billion savings from smart meters in the EU: How increasing the adoption of dynamic tariffs could make or break the EU's smart grid investment”, Energy Policy, n³8, October 2010, p. 6222-6231.

[10] FARUQUI A., HLEDIK R., NEWELL S., PFEIFENBERGER H., The Power of 5 Percent", The Electricity Journal, Vol.20, Issue, October 2007, p. 68-77.

[11] BORENSTEIN S., "The Trouble With Electricity Markets: Understanding California's Restructuring Disaster", The Journal of Economic Perspectives, Vol.16, ${ }^{\circ} 1$, January 2002, pp. 191-211

[12] BORENSTEIN S., JASKE M. and ROSENFELD A., "Dynamic Pricing, Advanced Metering and Demand Response in Electricity Markets", Center for the Study of Energy Markets, University of California Energy Institute, UC Berkeley. October 2002.

[13] BORENSTEIN S., "The Long-Run Efficiency of Real-Time Electricity Pricing", Center for the Study of Energy Markets (CSEM) Working Paper. CSEM WP 133R. February 2005.
[14] HANEY A. B., JAMASB T., POLLITT M. G., "Smart Metering and Electricity Demand: Technology, Economics and International Experience", Cambridge Working Paper in Economics 0905 \& EPRG Working Paper EPRG0903. February 2009.

[15] CHAO H., "Price-Responsive Demand Management for a Smart Grid World", The Electricity Journal, Vol.23, Issue 1, January-February 2010, p. 7-20.

[16] HOGAN W., "Providing Incentives for Efficient demand Response", Prepared for Electric Power Supply Association, Comments on PJM Demand Response Proposals, FERC Docket N EL09-68-000, 2009.

[17] TORRITI J, LEACH M., DEVINE-WRIGHT P., "Demand Side Participation: Price Constraints, Technical Limits and Behavioural Risks”, In: Jamasb, T. and Pollitt, M. (eds.). The Future of Electricity Demand: Customers, Citizens and Loads. Department of Applied Economics Occasional Papers (69). Cambridge University Press, Cambridge, 2011, p. 88-105

[18] VICKREY W.S., "Responsive Pricing of Public Utility Services", Bell Journal of Economics, Vol.2, Spring 1971, p. 337-346.

[19] FARUQUI A., WOOD L., "Quantifying the Benefits Of Dynamic Pricing In the Mass Market", The Brattle Group. Prepared for Edison Electric Institute. January 2008.

[20] WOLAK F, "Residential Customer Response to Real-Time Pricing: The Anaheim Critical-Peak Pricing Experiment", CSEM WP 151, May 2006

[21] OLMOS L., RUESTER S., LIONG S. J., GLACHANT J. M., "Energy Efficiency Actions Related to the Rollout of Smart Meters for Small Consumers", Florence School of Regulation, EUI RSCAS PP; 2010/02.

[22] FARUQUI A., SERGICI S., SHARIF A., (2010c), "The impact of informational feedback on energy consumption: a survey of the experimental evidence", Energy, Vol.35, April 2010, p. 1598-1608.

[23] SCHWEPPE F., CARAMANIS M., TABORS R., BOHN R., "Spot Pricing of Electricity", Kluwer, Boston Academic Press, 1988.

[24] RIOUS V., ROQUES F., PEREZ Y., "Which electricity market design to encourage the development of demand response?" Robert Schuman Centre for Advanced Studies, 2012, 25 p. (EUI Working Papers RSCAS 2012/12).

[25] IEA, "Electricity Information", 2012 Edition.

[26] EIA, "Projected Costs of Generating Electricity" 2010 Edition. 
VII. BIOGRAPHIES

Cedric Clastres is assistant professor in Economics at $P A C T E-E D D E N$ laboratory, University of Grenoble-Alpes. His research interests are in energy and competition in networks industries, using Industrial Organization and Regulatory Economics approaches. He has studied market design and regulatory policies to foster deployments in SG technologies.

Claire Bergaentzlé is $\mathrm{PhD}$ student at PACTE-EDDEN laboratory, University of Grenoble-Alpes, under supervision of Pr. Patrick Criqui. She is involved in the research field of smart grids technology adoption. Her main interests lie in the regulatory framework of network industries as well as the organization of power industries. 